\title{
Osteossíntese com placa em fratura de tíbia em potro de três meses
}

Kamila Pinheiro Paim, Raíssa Oliveira Leite, Tatiane Faria Prado, Eriky Akio Tongu, João Paulo Elsen Saut, Diego Jose Zanzarini

Delfiol, Geison Morel Nogueira"

*Autor correspondente

e-mail: geison.nogueira@ufu.br

\section{Resumo}

Fraturas de tíbia ocorrem com relativa frequência em equinos, sendo mais comuns em potros, e são resultantes de trauma. A carga da tíbia resulta em torque, possivelmente devido à angulação dupla das articulações femuro-tibio-patelar e do tarso. Em função disso, a maior parte das fraturas nesse osso apresenta a configuração espiral ou cominutiva. A imobilização com gesso, como método único de tratamento para fraturas completas diafisárias na tíbia, é pouco eficaz, sendo indicada a utilização de placas como a de compressão dinâmica. Relata-se o caso de uma potra, 3 meses de idade, $110 \mathrm{Kg}$, raça Quarto de Milha, que apresentava, à inspeção, claudicação grau 4, com aumento de volume na região da tíbia do membro pélvico direito, com ausência de solução de continuidade na pele ou exposição óssea. À palpação, observou-se sensibilidade dolorosa, instabilidade e crepitação na porção médio-proximal da tíbia direita. Ao exame radiográfico, nas projeções latero-medial e crânio-caudal, foi evidenciada fratura completa, diafisária, em espiral da tíbia. 0 tratamento instituido foi a ostessíntese com placa. 0 animal foi submetido à anestesia geral inalatória para a realização de acesso cirúrgico medial da tíbia. Foi aplicada na superfície medial do osso uma placa de compressão dinâmica de 4,5 mm, 9 furos, contemplando as porções diafisária, metáfise e epífise proximal. Além desta, também foram utilizados dois parafusos corticais de 4,5 mm na porção diafisária média cranialmente. Foi instituída antibioticoterapia profilática com ceftriaxona, na dose de $25 \mathrm{mg} / \mathrm{Kg}$, via intravenosa, a cada 12 horas, durante 10 dias; analgesia com cetoprofeno 2,2mg/Kg, via intravenosa, a cada 12 horas, por 3 dias; e, omeprazol, $4 \mathrm{mg} / \mathrm{kg}$, via oral, uma vez ao dia, durante 3 dias. Procedeu-se a avaliação radiográfica semanal, para acompanhamento dos posicionamentos interfragmentário e do implante. Aos sete dias pós-operatórios, observou-se o surgimento de uma linha de fratura incompleta, no fragmento proximal, longitudinalmente, sem comprometer, contudo, a estabilidade óssea. Aos 16 dias, foi possível observar, radiograficamente, o início da formação de calo ósseo, assim 
como um pequeno afastamento da extremidade proximal da placa em relação à superfície óssea e de três parafusos proximais. Por este motivo, associou-se a imobilização externa com gesso sintético, da terceira falange à metáfise distal do fêmur, mantendo o mesmo por 25 dias. Apesar das complicações após colocação do implante, a consolidação óssea seguiu curso normal, e decorridos 75 dias do procedimento cirúrgico, o animal recebeu alta. A utilização isolada da placa de compressão dinâmica de 4,5 mm foi insuficiente para o tratamento da fratura, sendo necessária a associação com gesso sintético como método de imobilização externa, para eficácia do tratamento.

Palavras-chave: Placa DCP. Equino. Cirurgia. 